\title{
Predictors of Housing Prices in Port Harcourt, Nigeria
}

\section{Richard Ugochukwu Elile, Valliappan Raju}

To Link this Article: http://dx.doi.org/10.6007/IJARBSS/v11-i11/11265

DOI:10.6007/IJARBSS/v11-i11/11265

Received: 14 September 2021, Revised: 18 October 2021, Accepted: 30 October 2021

Published Online: 07 November 2021

In-Text Citation: (Elile et al., 2021)

To Cite this Article: Elile, R. U., \& Raju, V. (2021). Predictors of Housing Prices in Port Harcourt, Nigeria. International Journal of Academic Research in Business and Social Sciences, 11(11), 723 - 734.

\section{Copyright: @ 2021 The Author(s)}

Published by Human Resource Management Academic Research Society (www.hrmars.com)

This article is published under the Creative Commons Attribution (CC BY 4.0) license. Anyone may reproduce, distribute, translate and create derivative works of this article (for both commercial and non-commercial purposes), subject to full attribution to the original publication and authors. The full terms of this license may be seen

at: http://creativecommons.org/licences/by/4.0/legalcode

Vol. 11, No. 11, 2021, Pg. $723-734$

Full Terms \& Conditions of access and use can be found at http://hrmars.com/index.php/pages/detail/publication-ethics 


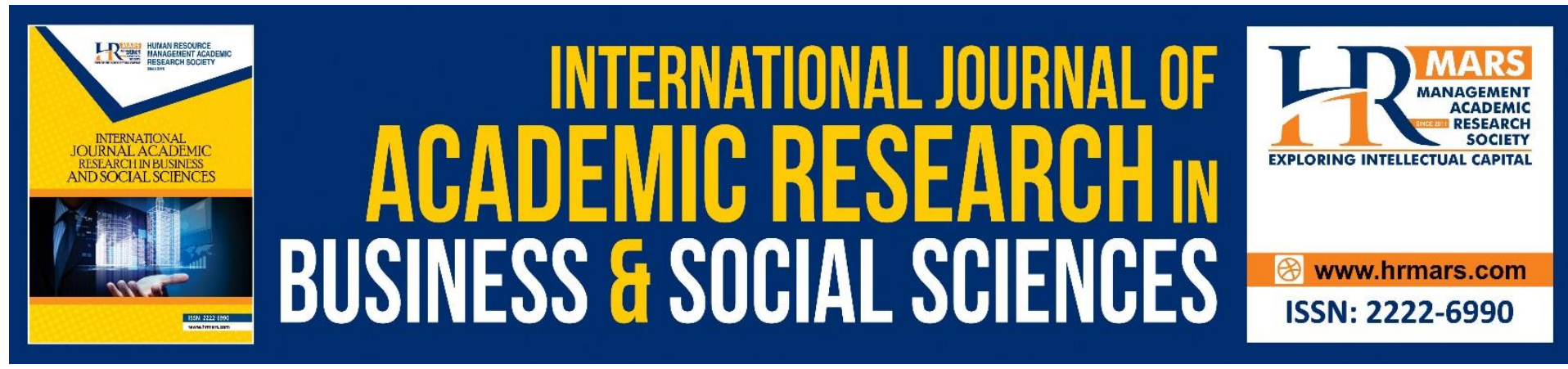

\title{
Predictors of Housing Prices in Port Harcourt, Nigeria
}

Richard Ugochukwu Elilea ${ }^{\mathrm{a}}$ Assoc. Prof Dr. Valliappan Raju

aPhD Candidate, Limkokwing University of Creative Technology, Malaysia, ${ }^{\mathrm{b}}$ Post Graduate Center, Limkokwing University of Creative Technology, Malaysia.

Email: richrune7@gmail.com

\begin{abstract}
Housing sector is generally the linchpin of every economic growth and development. The horizontal linkages and supports which real sector provides to other sectors, makes it, the true barometer to measure the performance of the economy. In most of the developed economies, the performance of the housing market is generally used to measure the trajectory of the economy in terms of job creation, consumer spending and macroeconomic stability. From the literature reviews, four factors were identified as the possible predicters of housing prices in Nigeria. The factors are (economic, land ownership, political and socialcultural). The survey study which was conducted in Porth Harcourt (capital of Rivers state) in Nigeria, was based on the sample of 220 real estate developers and managers who are involved in building and selling of houses in Porth Harcourt city, Nigeria. From the results of the study, economic factor has positive and significant effect on housing price. Second, land ownership has a negative and significant effect on housing price. Third, political factor has a positive and significant effect on housing price. Fourth, social-cultural factor has positive and significant effect on housing price. Policy informed implication were examined in the study.
\end{abstract}

Keywords: Economic, Land Ownership, Political, Social-cultural, Housing Price.

\section{Introduction}

Housing sector is generally the linchpin of every economic growth and development. The horizontal linkages and supports which real sector provides to other sectors, makes it, the true barometer to measure the performance of the economy. In most of the developed economies, the performance of the housing market is generally used to measure the trajectory of the economy in terms of job creation, consumer spending and macroeconomic stability (Iweala, 2014; Mukhtar et al., 2016). While economic incentives are expected to drive positive actions in terms of investments in the housing market (Akinyode, 2017; Trung \& Quan, 2019), the social and economic dislocations that impede access to affordable housing have not been addressed. According to United Nations (2018) report, it is projected that more than $60 \%$ of the world population are projected to live in cities by 2050 . It is estimated that increasing urbanization and rapid population growth where about 2.5 billion people would be added to the global population by 2050 (mostly in Africa and Asia) would present unprecedent challenges in housing sector (United Nations, 2018). 
Although researchers have tried to explore the relationships between macroeconomic factors and real estate investments in other to determine how macroeconomic factors, such as economic growth, interest rate and inflation rate affect housing market (Olatunji, Wahab, Ajayi \& Liman, 2017; Simon, Achsan, Munurung \& Sembel, 2015), most of the studies were conducted in developed countries with little interest from developing countries perspectives (Tze, 2013; Zhu, Sim, Zhang, 2015). Even though real estate investment is a function of economic conditions in a country (Mercylyne \& Kisanyanya, 2020; World Economic Forum, 2019), the underlying foundation of the macroeconomic factors which promote sustained economic prospects in real estate market have been neglected in many developing countries such as Nigeria. The aim of the study which is to determine the predictors of housing prices in Nigeria is structured as follows. The next section which is the literature review will examine past studies in other to contextualise the current study. Methodology section is devoted to method of conducting the study. Results, discussion and recommendation will follow accordingly.

\section{Literature Review}

Cost-effective housing is crucial in achieving the impending sustainable development challenges posed by increasing population and resultant urbanization. Although it is estimated that, there would be 43 megacities in the world comprising at least 10 million inhabitants (United Nations, 2018), most of the new megacities are expected to be located in Asia and Africa. With the emerging trends on urbanization and population growth, Nigeria and many other developing countries would be challenged to attain the sustainable development goals without targeted policy direction to invest in affordable housing. Affordable housing is the capacity of an individual or household to meet the housing needs in terms of cost and access (Akinyode, 2017).

\section{Economic Factors}

While affordable housing is important to achieve sustained development (Olatunji et al, 2017), the critical factors which determine, housing affordability in terms of cost, social and economic factors have not been properly examined in Nigeria. Affordable housing should be supported by business-friendly environment based on the right infrastructure, macroeconomic stability and social inclusion (World Economic Forum, 2019). Economic factors encompass various economic indicators which promote housing ownership in a particular area or locality. Economic factors such as interest rate, inflation rate and economic growth pattern affect investment in housing and associated housing infrastructure. Essentially, interest rate being the rate which determines the cost of funds, means that when the interest rate rises, cost of borrowing will increase with the concomitant increase in prices of housing (Zhang et al., 2012). Also, the negative influence of inflation on demand for housing investment has attracted rising discordant viewpoints. Andrews (2010) posits that rising inflation reduces consumer motivation to invest in real estate. Madsen (2012) argues that rising inflation pushes housing prices to rise with attendant lower demand for housing.

H1: Economic factors would have significant effect on housing prices in Nigeria.

\section{Land Ownership}

Improved housing investment depends on the efficient ways of land titling and registration. In an environment where land ownership is encumbered by traditional land ownership and tenure structure, real estate investment would be hampered (Trung \& Quan, 2019). In many 
Nigeria cities and localities, the pattern of land ownership which vested the full ownership and control of land in the office of the state governors, has made land acquisition for commercial real estate cumbersome. While this writer is not advocating for centrally controlled land ownership it is suggested that a streamlined process of land acquisition and titling which is less cumbersome and business friendly should be implemented (Onu \& Onu, 2012). Belke and Keil (2018) study on 100 Germane cities found that supply side in terms of land ownership and construction materials affect real estate investment. Trung and Quan (2019) found that legal factors have significant effect on housing development in Vietnam. They suggested the need to reform land titling and registration processes in other to attract sustained investment in the housing sector.

H2: Land ownership would have significant effect on housing prices in Nigeria.

\section{Political factors}

Although economic variables in the context of macroeconomic factors such interest rate, inflation rate and growth rate are believed to influence housing prices (Iweala, 2014; Mukhtar et al., 2016), the underlying political factors which influence critical aspects of real estate investments have been neglected. While the influence of economic factors has received substantial research attention in the study of housing ownership (Olatunji et al.,2017; World Economic Forum, 2017) political considerations which are believed to influence the development of cities in Africa and other developing countries have not been properly examined. Trung and Quan (2019) found significant effect of political factors on the housing prices in Vietnam. Glindro, Tientip, Jessica \& Haibin (2008) found a significant effect of political volatility and institutional efficiency on the price of real estate among nine Asia Pacific countries between 1993-2006.

H3: Political factors would have significant effect on housing prices in Nigeria.

\section{Social-cultural Factors}

Housing market is not only a function of economic and political factors but largely depend on wider social infrastructures. While government may influence demand and supply of housing with policies or legislations (World Economic Forum, 2017), it is the availability of the right social infrastructures in terms of social amenities, economic opportunities, safe and secure neighbourhoods that increase the prospects of real estate investments in a particular area or locality (Abul-atta \& El Damaty, 2019). Koske, Makokha and Namusonge (2016) found with a sample of 300 respondents that social-cultural factors have significant influence on the price of real estate. Ovsiannikova, Rabtsevich and Yugova (2021) established a significant influence of social-cultural factors on housing development. The study equally revealed the critical role of population income on housing development and the need to ensure a proper alignment between social-demographic factors and housing development policies. Razali et al (2021) found a positive and significant effect of social infrastructures and commercial real estate investment.

H4: Social factors would have significant effect on housing prices in Nigeria. 


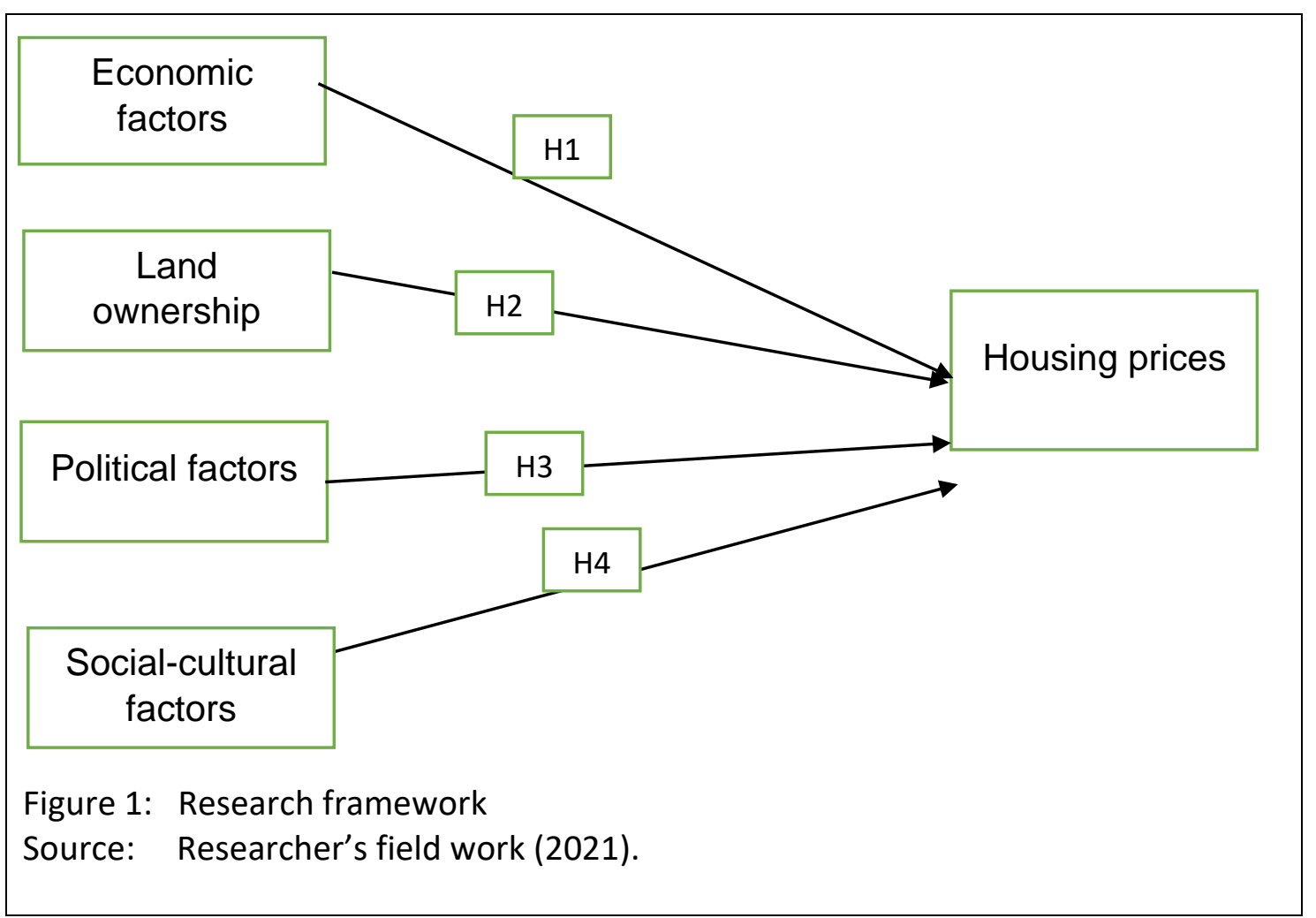

\section{Research Methodology}

From the literature reviews, four factors were identified as the possible predicters of housing prices in Nigeria. The factors are (economic, land ownership, political and social-cultural). The survey study which was conducted in Porth Harcourt (capital of Rivers state) in Nigeria, was based on the sample of real estate developers and managers who are involved in building and selling of houses in Porth Harcourt city, Nigeria. The questionnaire which was the preferred instrument of data collection was divided into two major parts ( $A$ and $B$ ). Part A covers the demographic information of the respondents while part $B$ contains the relevant questions for each of the four predictors (economic, land ownership, political and social-cultural). Out of 400 copies of the questionnaires which were distributed, 250 were returned while 220 copies were considered valid for the final analysis. Pilot study was conducted with a sample 50 respondents prior to the main study. The pilot study was instrumental in modifying the instruments for better comprehension by the respondents.

\section{Measurement}

The questionnaire items which were measured using a five-point Likert scale of increasingincreasing order of ( 1 = strongly disagree, $2=$ disagree, $3=$ neutral, $4=$ agree, $5=$ strongly agree). All the items were adapted from validated scales chosen from previous studies. Economic variable was measured with 4 items chosen from Trung and Quan (2019). Sample question includes: the average annual income of people in the area affects housing prices. Land ownership variable was measured with 5 items adapted from Trung and Quan (2019). Sample question includes: the ownership structure of land affects housing development. Political variable was measured with 5 variables of which 3 were adapted from Trung and Quan (2019) while 2 were self developed. Socio-cultural variable was measured with 4 items adapted from AL-Nahdi, Nyakwende, Banamah \& Jappie (2015). Finally, housing price was measured with 5 items adopted from AL-Nahdi (2015). 
Table 1: Demographic Profile of the Respondents $(\mathrm{N}=220)$

\begin{tabular}{lll}
\hline Characteristics & \multicolumn{1}{c}{ Frequency } & Percent (\%) \\
Gender & 150 & $77.27 \%$ \\
Male & 70 & $22.73 \%$ \\
Female & 220 & $100 \%$ \\
Total & & \\
Age group & 12 & $5.5 \%$ \\
$20-35$ & 67 & $30.5 \%$ \\
$36-46$ & 83 & $37.7 \%$ \\
$47-57$ & 58 & $26.4 \%$ \\
58 and above & 220 & $100 \%$ \\
Total & & \\
Educational level & 140 & $63.6 \%$ \\
Bachelor & 68 & $30.9 \%$ \\
Master & 12 & $5.5 \%$ \\
PhD & 220 & $100 \%$ \\
Total & & \\
Experience & 20 & $9.1 \%$ \\
$1-5$ & 85 & $36.6 \%$ \\
$6-10$ & 87 & $39.5 \%$ \\
$11-15$ & 8 & $3.6 \%$ \\
$16-20$ & 20 & $9.1 \%$ \\
21 and above & 220 & $100 \%$ \\
Total & &
\end{tabular}

From the information on Table $1,77.27 \%$ of the respondents are male while $22.73 \%$ are female. The male dominated sample distribution is consistent with real estate industry demography in Nigeria. From the perspective of educational level, all the respondents have at least a university degree while $94.5 \%$ of those surveyed were more than 35 years of age. Finally, more than $(52.27 \%)$ of the respondents have more than 10 years of work experience in the real estate business.

\section{Statistical Analysis and Findings}

Table 2: Reliability Analysis

\begin{tabular}{llll} 
Section & Variable & No of items & Cronbach alpha \\
\hline & & & $(\mathrm{Nn}=220)$ \\
\hline A & Economic factor & 4 & 0.906 \\
B & Land ownership & 5 & 0.864 \\
C & Political factor & 5 & 0.918 \\
D & Socia-cultural & 4 & 0.849 \\
E & Housing price & 5 & 0.755
\end{tabular}

Table 2 shows the reliability estimates of the five variables ranging from 0.918 (political) to housing price (0.755). According to Sekerang and Bougie (2010), reliability value of 0.70 and above is generally acceptable in social science study. From the information presented, it all the variables met the acceptability threshold. 
Table 3: Mean and Standard deviation

\begin{tabular}{llc}
\hline Variable & Mean & Standard deviation \\
\hline Economic factor & 3.93 & 0.86 \\
Land ownership & 3.82 & 0.87 \\
Political factor & 3.81 & 0.94 \\
Social-cultural & 3.69 & 1.04 \\
Housing price & 3.82 & 0.70 \\
\hline
\end{tabular}

Table 3 shows that economic factor has the highest value of mean and corresponding standard deviation (Mean:3.93, SD: 0.86), followed by land ownership (3.82, SD:0.87) and housing price respectively (Mean:3.82, SD: 0.70). Political factor (Mean:3.81, SD: 0.96) and social-cultural factor (Mean: 3.69, SD:1.04) completed the distribution. Effective data interpretation based on the mean value should be properly calibrated in other to explain the relative effect of the predictors (Michael, 2017). Five-point Likert scale according to Norasmah \& Salmah (2011) should be calibrated as follows: 1.00 -2.00 (low), 2.01-3.00 (moderately low),3.01-4.00 (moderately high), 4.01-5.00 (high). From the information on Table 3, it is evident that all the five variables are in the range of (3.01-4.00), which would be classified as moderately high. Essentially, economic factor which has the highest mean (3.93) is suggestive that economic factor is the most determining factor for housing prices followed by land ownership, political and social-cultural factors.

\section{Table 4}

\section{Correlation coefficient}

\begin{tabular}{lllll}
\hline & Economic & Land ownership & Political & Social-cultural \\
\hline Housing prices & $0.727^{* *}$ & $0.691^{* *}$ & $0.711^{* *}$ & $0.878^{* *}$ \\
(sig) & 0.000 & 0.000 & 0.000 & 0.000 \\
\hline
\end{tabular}

**. Correlation is significant at the 0.01 level (2-tailed).

From the information on Table 4 of the corelation coefficient, the four independent variables (economic, land ownership, political and social-cultural) factors have positive and significant relationships with the housing price. Specifically, social-cultural factor has the highest association with housing price $(r=0.878)$, followed by economic $(r=0.727)$, political $(r=$ $0.711)$ and land ownership ( $r=0.691)$.

Table 5

Regression Model (Model Summary)

\begin{tabular}{llll}
\hline$R$ & $R$ square & Adjusted R square & Standard Error \\
\hline 0.921 & 0.849 & 0.846 & 0.27851 \\
\hline
\end{tabular}

The " $R$ " which is the regression coefficient $(0.921)$ represents a strong coefficient model. The $\mathrm{R}$ square (0.849) which is the coefficient determination shows the proportion of variance in the housing price which was explained by the independent variables (economic, land ownership, political and social-cultural) factors. It may be inferred that the predictors (economic, land ownership, political and social-cultural) explains $84.9 \%$ of the variance in housing price. 


\section{Table 6}

ANOVA (Multiple Regression)

\begin{tabular}{llllll}
\hline Model & Sum of squares & df & Mean square & $F$ & Sig \\
\hline Regression & 93.502 & 4 & 23.376 & 301.354 & 0.000 \\
Residual & 16.677 & 215 & 0.078 & & \\
Total & 100.180 & 219 & & & \\
\hline
\end{tabular}

a. Dependent Variable: HOUSE.PRICE

b: Predictors: (Constant), SOCIA.CULT, LAND OWNER, ECONOMIC, POLITICAL.

Table 6 shows that, the four predicators economic, land ownership, political and socialcultural factors significantly predicted housing price because the test statistic is significant at 0.05 level of significance $([F(4,219)=301.354, p=0.000]$.

Table 7: Multiple Regression coefficients

\begin{tabular}{llllll}
\hline & \multicolumn{4}{l}{ Unstandardized coefficient } & \multicolumn{3}{l}{ Standardized coefficient } \\
& $\mathrm{B}$ & St. Error & $\mathrm{B}$ & $\mathrm{t}$ & $\mathrm{sig}$ \\
\hline (Constant) & 0.801 & 0.104 & & 0.768 & 0.000 \\
Economic factor & 0.199 & 0.030 & 0.242 & 0.674 & 0.000 \\
Land ownership & 0.147 & 0.029 & -0.182 & -5.046 & 0.000 \\
Political factor & 0.110 & 0.028 & 0.150 & 3.858 & 0.000 \\
Social-cultural & 0.340 & 0.031 & 0.501 & 11.088 & 0.000 \\
\hline
\end{tabular}

Table 7 of the multiple regression analysis shows the individual predictive capacity of each of the predictors (economic, land ownership, political and social-cultural) in predicting housing prices in Port Harcourt city, Nigeria. With respective to the research hypotheses, economic factor has a positive and statistically significant effect on housing prices $(\beta=0.242, p<0.005)$, $\mathrm{H} 1$ is accepted. Land ownership has a negative and statistically significant effect on housing prices $(\beta=0.182, p<0.005), \mathrm{H} 2$ is accepted. Political factor has a positive and statistically significant effect on housing prices $(\beta=0.150, p<0.005), \mathrm{H} 3$ is accepted. Social-cultural factor has a positive and statistically significant effect on housing prices $(\beta=0.501, p<0.005), H 4$ is accepted.

\section{Findings}

Housing market is one of the leading barometers for measuring economic growth and development. It follows that decline or underinvestment in housing market would have catastrophic consequences on the larger economic indicators. Although, the critical role of housing in the overall economic growth and development has been identified, little attention is paid on the core drivers of housing prices. From the results of the study, economic factor has positive and significant effect on housing price. Second, land ownership has a negative and significant effect on housing price. Third, political factor has a positive and significant effect on housing price. Fourth, social-cultural factor has positive and significant effect on housing price. The following interpretations may be gleaned from the findings. First, the 
positive and significant effect of economic factor on housing price is reflective of prevailing reality in the housing market. This finding is consistent with the assumption that, real estate market responds to broader economic conditions of an area (Mercylyne \& Kisanyanya, 2020; Olatunji et al., 2017; World Economic Forum, 2019).

Second, land ownership showed a negative and significant effect on housing price, which is suggestive that increase in land ownership would lead to decrease in housing price. Ownership structure of land has been a major impediment to the growth of housing market in many developing countries like Nigeria. From the results of the findings, an increase on the ownership structure of land in the context of streamlined ownership, tilting and registration of land would lead to more investment in the housing market, which would lead to lower housing price. Third, political factor was found to have a positive and significant effect on housing price, which is indicative that additional increase in political activities which are connected with housing policy and administration would lead to lower investment in housing market and attendant increase in housing prices. One of the major impediments to real estate investment in many developing countries and cities is the issue of government bureaucracy in housing policies.

\section{Discussions}

Housing is an important component of economic growth and development. As the linchpin of any sustained economic development, what happens in the housing sector determines the overall impact on the larger economic strata. While housing prices reflect the overall economic fundamentals such as interest rate, gross domestic product, national income and unemployment levels, social-cultural factors are often ignored when examining the predictors of housing prices. From the findings and in accordance with the objectives of the study, the following key insights are derived from the study. The positive and significant effect of economic factor on housing price is suggestive that, overall economic conditions would affect the housing prices in the following ways. First, positive economic sentiments in terms of economic growth, income pattern and interest rate would spur investments in housing. This result is consistent with the findings of Zhang et al (2012); Madsen (2012). Also, high inflation is believed to reduce consumer inclination to invest in housing which would affect the housing price. A contractionary interest rate policy which may be designed to curb rising prices could have unintended consequences on the wider economic conditions such as real estate investments. Furthermore, this finding is consistent with the IMF economic report which found that 33 out of the last 50 major banking crisis were caused by the pattern of boomburst cycle in the housing prices (Zhu, 2014). Accordingly, the finding suggests an integrated and coordinated economic policies to drive a robust and sustained housing market in developing countries and cities.

The second finding of the study showed a significant effect of land ownership on housing prices. Even though economic factors are believed to have significant effect on housing prices and resultant investment, the ownership pattern and associated regulations on land ownership would hamper or promote real estate investment, especially in developing country like Nigeria. The result of the finding is consistent with the findings from Belke and Keil (2018) and Trung and Quan (2019) who found that land ownership together with titling and registration processes are the major impediments to sustained investment in the sector. From the finding, the following interpretations may be drawn. First, the current land ownership in Port Harcourt city which limits large scale investments in real estate will continue to reduce house supply and concomitant increase on prices. Secondly, the finding indicates that, the 
current land ownership based on cultural attachment inhibits large scale investment in real estate which would have tampered the prices through supply-induced affordability.

The third finding suggests a significant effect of political factor on housing prices in Port Harcourt city. The finding which is consistent with the results from Trung and Quan (2019); Glindo et al (2008). Unlike developed cities with strong institutions, many developing cities are riddled with excessive political interference from government officials. Political factors in terms of permits and approvals from town planning officials have derailed substantial investments in real estate in many cities in Nigeria. The implication of this interference from supposedly supportive government officials hampers real estate investments and development in major cities in Nigeria. Political interferences affect city planning which makes strong investments on big ticket projects difficult. For example, high number of slums, unplanned and unregulated housing construction in the midst of rising population and ruralurban migration put enormous pressures on few available individually developed houses and concomitant high prices.

The fourth finding of the study shows a positive and significant effect of social-cultural factor on housing prices in Port Harcourt city. While economic and land ownership factors are believed to have immediate and significant effects on real estate investments (Onu \& Onu, 2012), it is the often neglected social-cultural factors in terms of modern amenities, safe and secured neighbourhoods that ultimately determine the long-term living pattern (World Economic Forum, 2017). The current finding on the role of social-cultural factors on housing prices is in agreement with the findings from Koske et al (2016); Ovsiannikova et al (2021). One of the major drawbacks on real estate investment in many cities in developing countries is the state of poor social infrastructures. The implication is that individuals are forced to develop their own houses based on their limited budgets which cannot provide the needed social amenities and modern infrastructures needed to drive large scale investments in real estate and resultant housing affordability.

\section{Conclusion}

Efficient housing market is crucial for sustained economic growth and development due to the its horizontal linkages with other industries. In many developing countries, housing market has remained weak and unresponsive to broader economic indicators due cultural and structural barriers. Four predictors were identified as the possible predictors of housing prices in Nigeria (economic, land ownership, political and social-cultural) factors. From the multiple regression model, economic, land ownership and social-cultural factors had positive and statistically significant effects on housing price while political factor had a negative and statistically significant effect on housing price. Although, housing market generally responds to changes in broader economic fundamentals, the findings of the current study answered some of the previously unanswered questions which have been neglected in many developing countries and cities. It is suggested that policy informed action should be directed at improving bureaucratic bottlenecks in the housing market. Second, social-cultural factor was found to have positive and significant effect on housing price.

Social-cultural factors in the context of improved social-cultural practices such as modern amenities, new and trendy life styles, gated and guarded neighbourhood are believed to push housing prices higher. Although, this writer is not advocating for retrogressing or backward social-cultural life style in other to reduce high prices, it is suggested that, this finding would enable policy informed action in the context of increase housing investment in other to increase the supply of modern houses at affordable prices. 


\section{References}

Abul-atta, T. A., \& El Damaty, D. S. (2019). Statically Analytical Study of Factors Affecting Real Estate Valuation of Residential Units. International Journal of Engineering Research and Technology, 12(8), 1247-1258.

Akinyode, B. F. (2017). Determining Factors for Housing Affordability in Ibadan, Nigeria. Ethiopian Journal of Environmental Studies \& Management, 10(5), 642 - 653.

AL-Nahdi, T. S., Nyakwende, E., Banamah, A. B., \& Jappie, A. A. (2015). Factors Affecting Purchasing Behavior in Real Estate in Saudi Arabia. International Journal of Business and Social Science, 6(2), 113-125.

Andrews, D. (2010). Real House Prices in OECD Countries: The Role of Demand Shocks and Structural and Policy Factors,. OECD Publishing. .

Belke, A., \& Keil, J. (2018). "Fundamental Determinants of Real Estate Prices: A Panel Study of German Regions. International Advances in Economic Research, 24, 25-45.

Glindro, E. T., Tientip, S., Jessica, S., \& Haibi, Z. (2008). Determinants of House Prices in Nine Asia-Pacific Economies. Bureau of International Settlements.

Iweala, N. O. (2014). Unleashing the housing sector in Nigeria and in Africall, paper presented at the 6th Global Housing Finance Conference. Washington: World Bank.

Koske, F. K., Makokha, E. N., \& Namusonge, G. S. (2016). Effect of Social-Cultural Factors on Real Estate Investment: A Survey of Kisumu City. European Journal of Business and Management, 8(29).

Madsen, J. B. (2012). A Behavioural Model of House Prices. Journal of Economic Behaviour \& Organization, 82, 21-38.

Mercylyne, I. J., \& Kisanyanya, A. G. (2020). The Effect of Macro-Economic Variables on Growth in Real Estate Investment in Kenya. IOSR Journal of Business and Management, 22(5), 60-80.

Michael, M. (2017). How can I transform a 7-likert type question into 3 qualitative categories (Low, Moderate, High). Retrieved from Reserachgate web site: https://www.researchgate.net/post/How_can_I_transform_a_7-

likert_type_question_into_3_qualitative_categories_Low_Moderate_High/5941c15f cbd5c24b8660fcf7/citation/download

Mukhtar, N. N., Amirudin, R., \& Mohamad, I. (2016). Housing delivery problems in developing countries: a case study of Nigeria. Journal of Facilities Management, 14(4), 315-329.

Norasmah, H. O., \& Salmah, I. (2011). Kecenderungan terhadap pemilihan kerjaya keusahawanan mengikut persepsi peserta skim usahawan siswa. Jurnal Teknologi, 56, 47-63.

'Olatunji, R. A., Wahab, B. M., Ajayi, M. T., \& Liman, H. S. (2017). Influence of Macroeconomic Factors on Residential Property Returns in Abuja, Nigeria. ATBU Journal of Environmental Technology, 10(1), 67-83.

Onu, V., \& Onu, A. C. (2012). Urban Residential Housing and Low-Income Earners: A Study of Makurdi Metropolis, Benue State, Nigeria. European Scientific Journal, 8(28), 231-246.

Ovsiannikova, T. Y., Rabtsevich, O. V., \& Yugova, I. V. (2021). Analysis of Housing Investment Market Dynamics Impact on Social and Economic Development. International science and technology conference, 1-12.

Razali, N. S., Menan, N. I., Teng, S. V., Ting, N. L., Mahayuddin, N. H., \& Rahman, M. A. (2020). Factors Affecting Industrial Property Value. International Journal of Scientific \& Technology Research Volume, 9(1), 211-217. 
Sekaran, U., \& Bougie, R. (2010). Research methods for business: A skill-building approach (5th ed.). West Sussex: Wiley.

Simon, Z., Achsan, N., Munurung, C., \& Sembel, R. (2015). The Determinants Of Rental Rate And Selling Prices of Office Spaces In Jakarta: A macroeconomic model using VECM approach. International Journal of Economics and Finance, 7(3).

Trung, P. C., \& Quan, N. T. (2019). Factors Affecting the Price of The Real Estate: A Case of Ho Chi. British Journal of Marketing Studies, 7(6), 35-45.

Tze, S. O. (2013). Factors Affecting the Price of Real Estate Properties in Malaysia. Journal of Emerging Issues in Economics, Finance and Banking, 1(5), 1-15.

United Nations. (2018). 68\% of the world population projected to live in urban areas by 2050 , says UN. Retrieved 27 September, 2021, from https://www.un.org/development/desa/en/news/population/2018-revision-ofworld-urbanization-prospects.html

World Economic Forum. (2019). Making Affordable Housing a Reality in Cities. Insight Report. Retrieved 27 September, 2021, from http://www3.weforum.org/docs/WEF_Making_Affordable_Housing_A_Reality_In_Ci ties_report.pdf

Zhang, Y., Hua, X., \& Zhao, L. (2012). Exploring Determinants of Housing Prices: A Case Study of Chinese Experience in 1999-2010. Economic Modelling, 29, 2349-2361.

Zhu, J. M., Sim, L. L., \& Zhang, Z. Q. (2015). Global Real Estate Investments and Local Cultural Capital in the Making of Shanghai's New Office Locations. Journal of Real Estate Research, 18(2), 197-217.

Zhu, M. (2014). Housing Markets, Financial Stability and the Economy. Retrieved 23 October, 2021, from IMF Speech:

https://www.imf.org/en/News/Articles/2015/09/28/04/53/sp060514 